\title{
PENERAPAN METODE BERNYANYI DALAM MENINGKATKAN PENGUASAAN KOSA KATA BAHASA ARAB DI MTS MA'ARIF NU 07 PURBOLINGGO
}

\author{
Ika Khoirun Nisa \\ Institut Agama Islam Negeri Metro, Lampung, Indonesia \\ ikanisa60@gmail.com \\ Novita Rahmi \\ Institut Agama Islam Negeri Metro, Lampung, Indonesia \\ novitarahmi85@yahoo.co.id \\ Walfajri \\ Institut Agama Islam Negeri Metro, Lampung, Indonesia \\ Walfajri2018@gmail.com
}

\begin{abstract}
This research aims to determine the application of singing method in improving Arabic vocabulary mastery at MTs Ma'arif NU 07 Purbolinggo. This research is a qualitative research. The subjects in this research were the principal, teachers and students. To obtain the data, the research usedinterview as the main method, observation and documentation as a supporting method. And descriptive analysis was used to analyze the data. The order of data analysis in this research is data reduction, data presentation and conclusion drawing. The results showed that the application of the singing method at MTs Ma'arif NU 07 Purbolinggo could improve students' ability to master vocabulary in Arabic. This couls be seen from the memorization of songs where the song lyrics had been replaced by Arabic vocabulary.
\end{abstract}

Keywords: Vocabulary Mastery, Arabic Language, Singing Method 


\title{
ملخص
}

هدف هذا البحث إلى تحديد تطبيق طريقة الغناء في ترقية إتقان المفردات العربية لدى الطلاب في المدرسة

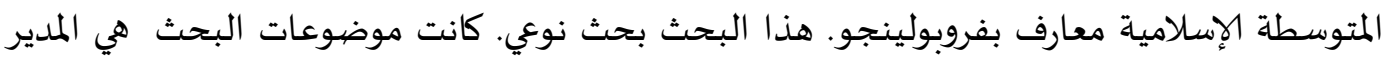
والمعلمين والطلاب. للحصول على بيانات فاستخدم البحث طريقة المقابلة، تعتبر طريقة رئيسية، وطريقة المراقبة والتوثيق كطريقتين داعمتين. ثم لتحليل البيانات كان يستغل التحليل الوصفي. ترتيب تحليل

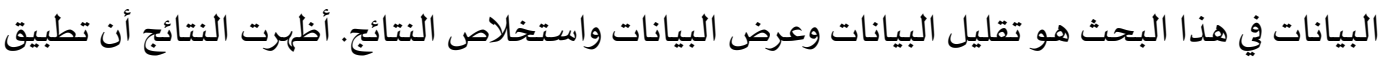
طريقة الغناء في هذه المدرسة يمكن أن يرقي قدرة الطلاب على إتقان المفردات باللغة العربية. يمكن

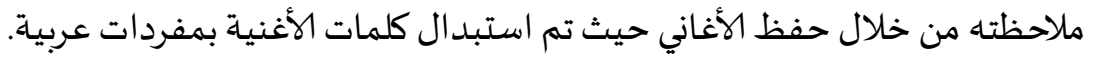
الكلمات الرئيسية: إتقان المفردات، اللغة العربية، طريقة الغناء

\begin{abstract}
Abstrak
Penelitian ini bertujuan untuk mengetahui penerapan metode bernyanyi dalam meningkatkan penguasaan kosa kata bahasa arab di MTs Ma'arif NU 07 Purbolinggo. Penelitian ini merupakan Penelitian Kualitatif. Subjek dalam penelitian ini adalah kepala sekolah, guru dan siswa. Untuk memperoleh data dalam penelitian ini dengan metode wawancara sebagai metode pokok, metode observasi dan dokumentasi sebagai metode penunjang. Kemudian untuk menganalisa data digunakan analisis deskriptif. Analisis data yang digunakan dalam penelitian ini yaitu reduksi data, penyajian data dan penarikan kesimpulan. Hasil penelitian menunjukkan bahwa penerapan metode bernyanyi di MTs Ma'arif NU 07 Purbolinggo dapat meningkatkan kemampuan siswa dalam menguasai kosa kata dalam bahasa Arab. Hal ini dapat dilihat dari hafalan nyanyian yang mana lirik lagunya sudah diganti dengan kosakata bahasa Arab.
\end{abstract}

Kata Kunci : Penguasaan Kosa Kata, Bahasa Arab, Metode Bernyanyi

\section{A. Pendahuluan}

Bahasa Arab merupakan bahasa asing di Indonesia. Namun demikian, bahasa arab memiliki peranan yang sangat penting bagi umat Islam. Bahasa Arab tidak bisa dipisahkan dari agama Islam. Dalam berbagai kegiatan keagamaan (ibadah) bahasa arab banyak digunakan seperti shalat, adzan, berdoa, membaca al-qur'an, dll. Selain itu, sumber pokok ajaran Islam yaitu al-qur'an dan hadist yang ditulis dalam bahasa arab. Demikian pula, kitabkitab tafsir, fiqih, ilmu hadist, dll juga ditulis dalam bahasa arab dan masih belum banyak diterjemahkan. Oleh karena itu, mempelajari bahasa arab 
merupakan hal yang sangat penting bagi umat Islam. Tanpa penguasaan yang baik tentang bahasa arab maka seseorang tidak bisa memahami ajaran Islam secara mendalam dan dengan pemahaman yang benar.

Dasar utama dalam belajar bahasa arab adalah kemampuan untuk memahami kosa kata bahasa arab. Sebab penguasaan kosa kata bahasa arab berkaitan erat dengan penguasaan keterampilan berbahasa (Mendengarkan, Berbicara, Membaca, dan Menulis). Tanpa penguasaan kosa kata yang baik, maka sulit bagi pelajar untuk menguasai kosa kata dengan baik pula. Sebaliknya penguasaan yang baik akan membantu pelajar untuk menguasai empat keterampilan bahasa tersebut. Dengan kata lain, penguasaan keterampilan bahasa arab memerlukan penguasaan kosa kata yang baik.

Dalam belajar bahasa arab, siswa harus menguasai kosa kata bahasa arab. Adapun proses dalam pembelajaran bahasa arab, kosa kata merupakan kategori paling penting dari semua kategori bahasa asing untuk dikuasai pada anak didik. Sehingga masih banyak siswa yang tidak bisa mengucapkan dengan benar kosa kata bahasa arab dan belum mengerti arti kosa kata bahasa dengan benar dan masih sedikit kosa kata yang dimiliki siswa.

Penguasaan kosa kata bahasa arab merupakan kemampuan dalam kata dasar belajar bahasa arab yaitu dapat menguasai kosa kata bahasa arab. Dengan demikian, penguasaan kosa kata meliputi kemampuan seperti mengucapkan dan menuliskan kata dengan benar, memahami makna kata, kemampuan menggunakan kosa kata tersebut dengan tepat.

Namun demikian, masih banyak pelajar bahasa arab yang belum menguasai kosa kata bahasa arab dengan baik. Diantara mereka masih belum mampu mengucapkan dan menuliskan dengan benar, sulit memahami makna kata bahasa arab baik dalam komunikasi lisan maupun dalam komunikasi tertulis seperti memahami teks bacaan. Selain itu mereka masih belum mampu menggunakan kosa kata bahasa arab dalam konteks kalimat yang tepat. 
Problematika pembelajaran kosa kata bahasa arab terdiri dari sistem kebahasaan dan non-kebahasaan. Problem kebahasaan dapat diartikan sebagai persoalan yang dihadapi siswa atau pengajar. Sedangkan non kebahasaan diartikan sebagai persoalan yang dapat mempengaruhi, kesuksesan dalam melaksanakan program pembelajaran, bahkan kegagalan lebih dominan. Adapun dalam permasalahan pembelajaran kosa kata bahasa arab hal yang perlu dilakukan adalah keseriusan siswa dalam belajar dan guru dalam mengajar. Oleh karena itu, perlu metode alternatif yang dapat membangkitkan semangat, minat dan motivasi dalam belajar bahasa arab.

Salah satu metode yang dapat diterapkan dalam pembelajaran kosa kata bahasa arab adalah metode bernyanyi. Metode merupakan suatu cara dan siasat penyampaian bahan pelajaran tertentu dari suatu mata pelajaran agar siswa dapat mengetahui, memahami, dan mempergunakan dengan kata lain menguasai bahan pelajaran tersebut untuk mencapai hasil efektif efisien (T. Y. S. Anwar, 1997). Sedangkan bernyanyi merupakan salah satu aktifitas yang sangat disenangi oleh sebagian besar masyarakat, terutama oleh anakanak (Yusriana, 2012). Seorang siswa akan lebih mudah untuk mengingat suatu pelajaran dengan proses belajar yang menyenangkan. Sehingga metode bernyanyi menjadi salah satu metode yang dapat menarik siswa dalam belajar kosa kata bahasa Arab. Dengan menerapkan metode bernyanyi dalam pembelajaran kosa kata bahasa arab diharapkan siswa dapat meningkatkan kosa kata bahasa arab.

Pembelajaran bahasa arab siswa kelas VII MTs Ma'arif NU 07 Purbolinggo, masih banyak pelajar yang belum menguasai kosa kata bahasa arab dengan baik. Diantara mereka masih belum mampu mengucapkan dan menuliskan dengan benar, sulit memahami makna kata bahasa arab baik dalam komunikasi lisan maupun dalam komunikasi tertulis seperti memahami teks bacaan. Selain itu mereka masih belum mampu menggunakan kosa kata bahasa arab dalam konteks kalimat yang tepat. 
Dari observasi awal yang telah dilakukan oleh peneliti di MTs Ma'arif NU 07 Purbolinggo kaya akan penerapan metode pembelajaran termasuk pembelajaran bahasa Arab khususnya lagi dalam penguasaan kosakata bahasa Arab. Penulis tertarik untuk mengamati sejauh mana proses yang dilakukan guru di sekolah tersebut dalam penerapan teknik bernyanyi.

Pada penelitian ini didukung oleh beberapa penelitian-penelitian terdahulu. Adapun penelitian relevan yang berkaitan dengan penelitian ini yaitu di antaranya sebagai berikut: Artikel jurnal dengan judul: "Penggunaan Teknik Bernyanyi untuk Meningkatkan Penguasaan Kosa-Kata Bahasa Arab pada Anak Usia Dini". Penelitian ini bertujuan untuk meningkatkan pemerolehan kosakata bahasa Arab pada anak usia dini dengan teknik bernyanyi. Hasil penelitian menunjukkan bahwa siswa anak usia dini senang belajar bahasa Arab dengan bernyanyi dan lebih mudah mengingat kosakata yang telah diajarkan oleh guru.

Artikel jurnal selanjutnya yang ditulis oleh Barokatussolihah, dengan judul Upaya Meningkatkan Penguasaan Mufrodat Bahasa Arab melalui Metode Bernyanyi di Kelas VII A MTsN Donomulyo Kulon Progo". Penelitian ini dilaksanakan di MTsN Donomulyo Nanggulan Kulon Progo dengan mengambil sampel kelas VII A yang berjumlah 21 siswa Tahun Pelajaran 2014/2015. Penguasaan mufrodat siswa di kelas ini ketika dengan menggunakan metode Bernyayi mengalami peningkatan.

Berikutnya, Wiwin Fachrudin Yusuf dan Imatuzzahiro dalam tulisannya "Metode Bernyanyi Arab dengan Menggunakan Media Eraser Walk dalam Meningkatkan Hafalan Kosakata Bahasa Arab". Dalam penelitian ini, metode yang digunakan guru sangat membantu siswa untuk menambah atau mengasah kemampuan mengingat kosakata karena dibuat permainan dan menyenangkan siswa. Dari permainan ini bisa membuat siswa merasa senang dan enjoy ketika menggunakan metode ini. 
Dari permasalahan yang muncul diatas maka penulis tertarik untuk memaparkan tentang penerapan metode bernyanyi dalam meningkatkan penguasaan kosa kata bahasa arab di MTs Ma'arif NU 07 Purbolinggo.

\section{B. Pembahasan}

\section{Penguasaan Kosakata Bahasa Arab dan Metode Bernyanyi}

a. Penguasaan Kosa Kata Bahasa Arab

Penguasaan adalah suatu perbuatan untuk menguasai atau memahami sebuah teori. Menurut Kamus Besar Bahasa Indonesia, penguasaan berasal dari kata kuasa yang mendapat imbuhan pe-an yang artinya proses, cara, perbuatan menguasai atau pemahaman untuk menggunakan (pengetahuan, kepandaian, dsb) (Penyusun, 2005). Jadi penguasaan adalah memahami suatu teori dan mampu menerapkan teori tersebut.

Kosa kata dalam bahasa arab disebut dengan Mufrodat. Menurut Ali Al-Khuli mufradat adalah satuan bahasa terkecil yang berdiri sendiri, kata terkadang berupa kata dasar dan terkadang berupa kata berimbuhan. Selain itu, setiap kata memiliki bentuk dan makna, serta fungsinya masing-masing (Al-Khuli, 2010). Menurut Rochayah Machali, kata merupakan unsur utama pembentuk struktur frase dan terdapat dua unsur utama dalam kata, yaitu kata dasar dan imbuhan (akhiran, awalan, atau sisipan) (Machali, 2009). Sedangkan menurut H.M. Abdul Hamid dkk. mufradat merupakan bagian terpenting dari bahasa yang menjadi tuntutan dan syarat dasar dalam pembelajaran bahasa Arab (Hamid et al., 2008). Jadi mufradat adalah satuan bahasa Arab terkecil yang berdiri sendiri, menjadi penyusun kalimat, serta menjadi syarat dasar dalam pembelajaran bahasa Arab.

Kosa kata merupakan suatu komponen atau unsur yang sangat penting dan merupakan tuntutan serta syarat dasar dalam pembelajaran bahasa arab. Dengan penguasaan kosa kata yang cukup, 
siswa dapat mengikuti pembelajaran bahasa arab dengan lebih mudah (Qodariyah, 2016). Kosa kata (mufrodat) merupakan salah satu unsur terpenting dalam bahasa termasuk bahasa arab, disamping kaidah tata bahasa atau ilmu nahwu (sintaksis), ilmu shorof (morfologi), dan ilmu ashwat (fonetik). Oleh karenanya mempelajari atau memperluas kosa kata merupakan persyaratan dan tuntutan yang mendasari seseorang dalam menguasai bahasa arab tersebut (Fajriah, 2015).

Adapun menurut syaiful mustofa, kosa kata (mufrodat) merupakan himpunan kata atau khazanah kata yang diketahui oleh seseorang atau estintensi lain yang merupakan bagian dari suatu bahasa tersebut (Mustofa, 2011). Sehingga untuk mengetahui kemampuan kosa kata bahasa arab dengan standar kemampuannya bertujuan dalam pendidikan, kosa kata seperti yang dijelaskan oleh Syaiful mustofa dibawah ini :

1) Memperkenalkan kosa kata baru kepada siswa atau mahasiswa, baik melalui bacaan maupun fahm-al-Musnu'.

2) Melatih siswa untuk dapat melafalkan kosakata itu dengan baik dan benar.

3) Memahami makna kosa kata baik secara intonasi maupun leksikal.

4) Mampu mengapresiasi dan memfungsikan mufradat itu dalam berekspresi lisan (berbicara) maupun tulisan (mengarang) sesuai dengan konteknya yang benar (Mustofa, 2011).

Adapun teknik mengetahui kemampuan kosa kata menurut Abdul Hamid :

1) Memberi padaan kata (sinonim) : guru dapat memberikan padaaan bagi kosa kata yang hendak diajarkan seperti ketika mengajarkan kata qoada, guru dapat menyebutkan sinonimnya yaitu jalasa.

2) Memberi lawan kata (Antonim) : guru dapat memberikan kata yang maknanya berlawanan dengan kosakata yang hendak 
diajarkan,seperti guru dapat menjelaskan kata thawil dengan menyebutkan lawan katanya yaitu qashir.

3) Memberikan asosiasi makna : guru dapat menjelaskan kata madrasah dengan memberikan asosiasi dengan menyebutkan kata kata seperti : thalib, mudaris, sabburah, dan lain lainnya, sehingga pikiran siswa akan tertuju pada satu pengertian yaitu sekolah.

4) Meminta siswa membaca berulang kali : guru bisa meminta siswa membaca kosakata baru yang didapatkan dari sebuah teks berulang kali, sehingga diharapkan dia dapat menemukan artinya setelah merangkainya dengan kata yang lain dalam teks yang dibacanya (Hamid, 2001).

Dari penjelasan tersebut bisa ditarik kesimpulan bahwa penguasaan mufradat adalah pemahaman atau kemampuan seseorang untuk menggunakan mufradat (kata) dalam komunikasi yang sesungguhnya. Selain mengetahui bentuk, makna dan fungsinya juga mampu melafalkan dan menuliskan mufradat tersebut dengan baik dan benar.

Penguasaan kosa kata bahasa arab merupakan kemampuan dalam kata dasar belajar bahasa arab yaitu dengan bisa menguasai kosa kata bahasa arab. Penguasaan bahasa bertujuan agar manusia dapat berkomunikasi dengan baik, maka seorang pembelajar harus menguasai kosa kata karena kosa kata akan banyak membantu siswa dalam belajar bahasa asing (bahasa arab)(Prastiya, 2013). Kekayaan kosa kata seseorang secara umum dianggap merupakan gambaran dari tingkat pendidikannya (Riyadi, 2014).

Penguasaan kosa kata dalam bahasa arab sangatlah penting karena berguna untuk belajar keterampilan bahasa yaitu mendengar, menulis, membaca dan berbicara dalam pelajaran bahasa arab. Beberapa orang mungkin menganggap bahwa mempelajari pelajaran 
bahasa asing (bahasa arab) berarti mampu menerjemahkannya kedalam bahasa nasionalisme.

b. Bentuk-Bentuk Mufrodat

Mufradat terbagi menjadi tiga macam, yaitu: isim, fi'il , dan huruf (Al-Ghalayini, 2005). Adapun penjelesannya sebagai berikut:

1) Isim adalah kata yang menunjukkan makna dengan sendirinya dan tidak disertai dengan pengertian zaman. Dengan kata lain, isim adalah kata benda.

2) Fi'il adalah kata yang menunjukkan makna dengan sendirinya dan disertai pengertian zaman. Macam-macam fi'il ada tiga: fi'il madi untuk menunjukkan kejadian dimasa lalu dan telah selesai, fi'il mudhari' untuk menunjukkan kejadian yang sedang berlangsung dan yang akan datang, dan fi'il amr untuk menunjukkan kejadian pada masa yang akan datang (M. Anwar \& Bakar, 1995).

3) Huruf adalah kata yang menunjukkan makna apabila digabungkan dengan kata lainnya dan tidak memiliki alamat seperti isim dan fi"il.

c. Makna Mufrodat

Makna sebuah mufradat dapat dibedakan menjadi dua, yaitu makna denotatif (ashli) dan makna konotatif (idofi)(Efendi, 2005). Makna denotatif adalah makna yang terdapat dalam kamus atau makna obyektif yang disepakati oleh semua orang. Makna ini merupakan makna umum yang tidak dipengaruhi oleh pengalaman atau perasaan seseorang. Sedangkan Makna konotatif adalah makna tambahan yang terkandung didalamnya nuansa atau kesan khusus sebagai akibat dari pengalaman para pemakai bahasa (Efendi, 2005).

d. Pengertian Metode Bernyanyi

Metode adalah suatu cara yang digunakan untuk mencapai tujuan tertentu yang telah ditetapkan sebaelumnya. Dalam kegiatan belajar mengajar, metode sangat diperlukan oleh guru, dengan 
penggunaan yang bervariasi sesuai dengan tujuan yang ingin dicapai. Menguasai metode mengajar merupakan keniscayaan, sebab seorang guru tidak akan dapat mengajar dengan baik apabila ia tidak menguasai metode secara tepat (Fathurrohman \& Sutikno, 2011).

Sedangkan menyanyi adalah mengeluarkan suara bernada, berlagu (dengan lirik atau tidak) (Depdiknas, 2011). Menurut Novi Mulyani Menyanyi merupakan kegiatan yang menyenangkan bagi anak-anak. Pengalaman menyanyi sebagai salah satu pengalaman musik yang memberi kepuasan dan kebahagiaan bagi mereka (Mulyani, 2017).

Dari pengertian diatas dapat disimpulkam bahwa Metode bernyanyi merupakan metode pembelajaran yang menggunakan nyanyian sebagai sarana belajar pada peserta didik sehingga kegiatan menjadi menyenangkan dan membahagiakan.

1) Kelebihan Metode Bernyanyi

Adapun kelebihan metode bernyanyi dalam proses belajar mengajar yaitu :

a) Memperkaya atau menambah sumber belajar bagi guru dan anak usia dini.

b) Memotivasi guru untuk lebih kreatif dalam mengoptimalkan lingkungan sekitar untuk dijadikan sebagai media pembelajaran.

c) Meningkatkan kreativitas guru dalam menciptakan metode pembelajaran yang menarik dan menyenangkan untuk anak usia dini.

d) Materi pembelajaran akan menjadi lebih menarik dan konkret.

e) Untuk anak didik, diharapkan dapat merangsang kemampuan penalarannya, penciptaan, perkembangan daya pikir, perkembangan bahasa, berimajinasi dan kretivitas. 
f) Membantu anak untuk mengembangkan pengetahuan dan ketrampilan baru yang didasarkan pada hal-hal yang telah anak ketahui dan yang ingin diketahui anak.

g) Bernyanyi harus menyediakan konsep yang dapat diselidiki oleh setiap anak melalui pengalaman praktik langsung tentang objek-objek yang nyata bagi anak untuk menilai dan memanipulasinya.

h) Bernyanyi dapat disesuaikan dengan tema, materi dan kegiatan yang berlangsung.

i) Anak menjadi aktif terlibat di dalam kegiatan, sehingga anak akan menggunakan semua pemikirannya.

j) Hasil yang capai dari penerapan metode bernyanyi secara tidak langsung menghasilkan produk kreativitas.

k) Guru dapat memberikan kesempatan kepada anak untuk merefleksikan apa yang telah anak ketahui.Meningkatkan kemandirian, harga diri yang positif (percaya diri).

2) Kekurangan Metode Bernyanyi

Kalau dilakukan tanpa diikuti metode-metode lainnya, maka tujuan pembelajaran yang dicapai sedikit terbatas, misalnya hanya mengembangkan kecerdasan musik saja. Sulit digunakan pada kelas besar, hasilnya akan kurang efektif pada anak pendiam atau tidak suka bernyanyi, suasana kelas yang ramai, bisamengganggu kelas yang lain (Nikmah, 2017).

Dari uraian diatas, metode bernyanyi sangat berperan penting dalam proses pembelajaran di sekolah, yaitu :

a) Anak akan berusaha mengatakan apa yang ada dalam pikirannya dengan kalimat-kalimat pendek. Kalimat yang terdiri dari satu kata atau dua kata. 
b) Dengan kosakata yang diajarkan dan didengarkan oleh anak, maka anak akan mampu memahami maksud kosakata bahasa yang baru diketahuinya

c) Dengan kosakata yang baru diketahuinya, anak didik mampu berbicaradengan baik di lingkungannya.

d) Kosakata merupakan bekal membaca dan menulis anak untuk memasuki usia sekolah khususnya kelas satu SD/MI.

3) Langkah-langkah metode bernyanyi

Untuk memperoleh hasil belajar yang optimal melalui metode menyanyi pada kegiatan pembelajaran tentu ada langkah prosedur yang harus dipersiapkan oleh guru. Berapa hal yang perlu diperhatikan dalam langkah-langkah metode bernyanyi, yaitu :

a) Guru mengetahui dengan jelas isi pokok materi yang akan diajarkan.

b) Merumuskan dengan benar informasi atau konsep ataupun fakta materi baru apa saja yang harus dikuasai/dihafalkan oleh peserta didik.

c) Memilih nada lagu yang familiar dikalangan peserta didik.

d) Menyusun informasi konsep/fakta/materi yang kita inginkan untuk dikuasai peserta didik ke dalam bentuk lirik lagu yang disesuaikan dengan nada lagu yang dipilih.

e) Guru harus mempraktikan terlebih dahulu menyanyikannya.

f) Mendomentrasikannya bersama-sama secara berulang-ulang.

g) Usahakan untuk diikuti dengan gerak tubuh yang sesuai.

h) Mengajukan pertanyaan seputar materi tersebut untuk mengukur apakah siswa sudah dapat menghafal dan menguasainya melalui lagu yang dinyanyikan tersebut(Mashuri \& Dewi, 2017). 
4) Manfaat Metode Bernyanyi

Sesungguhnya setiap manusia mempunyai tingkat kejenuhan yang sangat tinggi sehingga dibutuhkannya ketenangan jiwa yaitu dengan cara bernyanyi. Adapun manfaat dari metode menyanyi sangatlah penting untuk anak-anak antara lain:

a) Menimbulkan rasa senang dan gembira dalam diri seorang anak

b) Memperkaya imajinasi si anak dan meningkatkan daya kreasinya.

c) Meningkatkan jiwa seni dan sastra dalam diri mereka

d) Meningkatkankemampuan berbahasa

e) Meningkatkan kemampuannya untuk mengkritik dan melakukan pembenaran.

f) Mencerdaskan akal membina jiwa dan meningkatkan imajinasinya

g) Menambah kecintaan si anak pada sastra dan seni (Mursy, 2001).

Metode ini dapat diartikan sebagai cara alternatif untuk melakukan aktivitas kegiatan belajar bahasa arab dengan tujuan mempermudah pembelajaran yang diinginkan.

2. Metode Penelitian

Jenis penelitian ini merupakan kualitatif yaitu penelitian yang temuan-temuannya tidak diperoleh melalui prosedur kuantifikasi, perhitungan statistik, atau bentuk cara-cara lainnya yang menggunakan ukuran angka. Penelitian ini menggunakan pendekatan kualitatif karena adanya keunikan metode bernyanyi dalam meningkatkan mufradat dalam pembelajaran bahasa Arab di MTs Ma'arif NU 07 Purbolinggo. Keunikan tersebut yakni karena di sekolah tersebut memiliki banyak kegiatan kebahasaan untuk penunjang pengembangan bakat dan keterampilan peserta didik terutama dalam kosakata (mufradat) bahasa Arab. 
pembelajaran bahasa Arab menggunakan teknik bernyanyi sangat membantu siswa untuk menghafal kosakata-kosakata dalam bahasa Arab. Dapat dilihat dari hafalan nyanyian yang mana lirik lagunya sudah diganti dengan kosakata bahasa Arab. dan masih banyak kegiatan lain yang mengasah peserta didik dalam berbahasa Arab.

Adapun beberapa teknik pengumpulan data yang peneliti gunakan yaitu berupa observasi, tes, wawancara, dan dokumentasi. Subjek penelitian ini adalah Guru Bahasa Arab dan Kepala MTs Ma'arif NU 07 Purbolinggo. Subjek penelitian memberikan informasi tentang pembelajaran/ kegiatan bahasa Arab di MTs Ma'arif NU 07 Purbolinggo. Dalam penelitian ini, model analisis data yang digunakan adalah analisis deskriptif. Dalam memeriksa keabsahan data, peneliti menggunakan riangulasi sumber.

3. Penerapan Metode Bernyanyi di MTs Ma'arif NU 07

Observasi dilakukan di MTs Ma'arif NU 07 Purbolinggo. Berdasarkan penelitian yang dilakukan oleh peneliti, pembelajaran bahasa Arab menggunakan teknik bernyanyi sangat membantu siswa dalam menghafal kosa kata dalam bahasa Arab. Hal ini dapat dilihat dari hafalan nyanyian yang mana lirik lagunya sudah diganti dengan kosakata bahasa Arab.

Kegiatan bernyanyi merupakan salah satu kegiatan yang disenangi oleh anak-anak. Berdasarkan wawancara dengan Anisa, Guru Bahasa arab MTs Ma'arif NU 07 Purbolinggo pada tanggal 09 Juli 2020, hampir semua anak sangat menikmati lagu atau nyanyian yang didengarkan. Guru bahasa Arab mengungkapkan bahwam metode bernyanyi merupakan metode pembelajaran yang bertujuan agar peserta didik mampu menguasai dan mengingat materi dengan baik. Metode bernyanyi bernyanyi membuat suasana belajar menjadi riang dan bergairah sehingga perkembangan anak dapat distimulasi secara lebih optimal. 
Pada dasarnya semua siswa senang mendengarkan, menyanyikan, dan belajar dengan nyanyian/lagu. Oleh karena itu musik secara umum merupakan bagian penting dari proses belajar-mengajar bagi siswa. Hampir semua bentuk nyanyian dari yang tradisional sampai dengan yang pop dapat dimanfaatkan oleh guru dalam pembelajaran.

Penerapan Metode Bernyanyi di MTs Ma'arif NU 07 Purbolinggo menunjukkan bahwa kegiatan perencanaan pembelajaran untuk meningkatkan kemampuan untuk menguasai kosa kata bahasa arab dilaksanakan dengan sangat baik. Kegiatan pembelajaran dimulai dengan mengucapkan salam dilanjutkan berdoa secara bersama dan mengecek kehadiran siswa. Kemudian menjelaskan tema kegiatan yang akan dilaksanakan. Guru memperkenalkan lagu dan menyanyikannya secara bersama-sama. Dalam hal ini lagu diganti dengan kosa kata nama-nama benda yang ada di dalam kelas. Kegiatan ini didukung dengan menggukan media proyektor untuk menampilkan gambar nama-nama benda yang sudah disusun sesuai lagu. Setelah itu guru menanyakan kepada siswa tentang pelajaran yang sudah didapatkan. Kegiatan ditutup dengan menyanyikan lagu kembali,kemudian berdoa dan guru memberikan salam penutup.

Berdasarkan pengamatan yang dilakukan peneliti, Guru sudah baik dalam menggunakan metode dan media pembelajaran pada proses belajar mengajar. Guru sudah menunjukkan penguasaan materi yang mengaitkan dengan pengetahuan yang sesuai dengan tema. Guru juga sudah melaksanakan pembelajaran secara sitematis dalam melaksanakan pembelajaran dengan waktu yang telah dialokasikan.

Hasil pembelajaran melalui metode bernyanyi dalam meningkatkan penguasaan kosa kata, membuat anak lebih antusias dan peran keterlibatan siswa pada saat pelaksanaan metode bernyanyi lebih dominan. Kemudian Komunikasi antar peserta didik terjalin secara aktif. Selain itu komunikasi antar guru dengan peserta didik terlihar efektif dan 
komunikatif. Dengan menerapkan metode bernyanyi, penguasaan kosa kata bahasa arab siswa menjadi meningkat. Hal ini terlihat pada siswa yang dijadikan objek penelitian.

\section{SIMPULAN}

Penerapan metode bernyanyi Arab dalam meningkatkan penguasaan kosa kata bahasa arab di MTs Ma'arif NU 07 Purbolinggo, guru menyiapkan materi yang ingin dikuasai siswa kedalam bentuk lirik, kemudian guru mempraktikkan terlebih dahulu. Setelah itu guru mengatur tempat mempraktikkannya secara bersama-sama. Selanjutnya guru memberi kesimpulan mengenai materi dan metode yang telah usai dilaksanakan.

Berdasarkan pengamatan yang dilakukan peneliti, Guru sudah baik dalam menggunakan metode dan media pembelajaran pada proses belajar mengajar. Hasil pembelajaran melalui metode bernyanyi dalam meningkatkan penguasaan kosa kata, membuat siswa lebih antusias, komunikasi menjadi aktif dan interaktif baik antar sesama siswa maupun siswa dengan guru. Dengan demikian dapat disimpulkan bahwa penerapan metode bernyanyi dapat meningkatkan penguasaan kosa kata bahasa arab di MTs Ma'arif NU 07 Purbolinggo. 


\section{Daftar Pustaka}

Al-Ghalayini, M. (2005). Jami' Al-Durus Al-Arabiyyah. Ashriyyah.

Al-Khuli, M. A. (2010). Strategi Pembelajaran Bahasa Arab. Basan Publishing. Anwar, M., \& Bakar, A. A. (1995). Ilmu Nahwu Terjemahan Matan AlJurumiyyah dan Imrithy Berikut Penjelaasannya. Sinar Baru Algesindo.

Anwar, T. Y. S. (1997). Metodologi Pengajaran Agama dan Bahasa Arab. Raja Grafindo Persada.

Depdiknas. (2011). Kamus Besar Bahasa Indonesia. PT. Gramedia Pustaka Umum.

Efendi, A. F. (2005). Metodologi Pengajaran Bahasa Arab. Miskat.

Fajriah, Z. (2015). Peningkatan Penguasaan kosa kata bahasa arab (mufrodat) melalui penggunaan media Kartu Bergambar. Jurnal Pendidikan Anak Usia Dini, 9(1).

Fathurrohman, P., \& Sutikno, S. (2011). Strategi Belajar Mengajar Melalui Penanaman Konsep Umum dan Konsep Islami. PT. Refika Aditama.

Hamid, M. A. (2001). Mengukur Kemampuan Bahasa Arab. UIN-Maliki Press.

Hamid, M. A., Baharuddin, U., \& Mustofa, B. (2008). Pembelajaran Bahasa Arab (Pendekatan, Metode, Strategi, Materi, dan Media). UIN Malang Press.

Machali, R. (2009). Pedoman bagi Penerjemah: Panduan Lengkap bagi Anda yang Ingin Menjadi Penerjemah Profesional. Kaifa.

Mashuri, \& Dewi, M. (2017). Penerapan Metode Bernyanyi dan Media Flah Card untuk Meningkatkan Daya Ingat Anak dalam Pengenalan Huruf Hijaiyyah di TPA Darul Falah Gampong Pineung. Jurnal Mudarrisuna, $7(2)$.

Mulyani, N. (2017). Pengembangan Seni Anak Usia Dini. PT. Remaja Rosdakarya.

Mursy, M. S. (2001). Seni Mendidik Anak. Arroyan.

Mustofa, S. (2011). Strategi Pembelajaran Bahasa Arab Inovatif. Maliki Press.

Nikmah, K. (2017). Penggunaan Teknik Bernyanyi untuk Meningkatkan 
Penguasaan Kosa Kata Bahasa Arab Pada Anak Usia Dini. Dar El-Ilmi: Jurnal Studi Keagamaan, Pendidikan, Dan Humaniora, 4(2).

Penyusun, T. (2005). Kamus Besar Bahasa Indonesia. Balai Pustaka.

Prastiya, S. (2013). Menyanyi Sebagai Metode Untuk Meningkatkan Penguasaan Kosa Kata Bahasa Arab Santriwan-Santriwati Kelas Umar Bin Khatab TPA Masjid Pengeran Diponegoro Yogyakarta. UIN Sunan Kalijaga.

Qodariyah, L. (2016). Pembelajaran Mufrodat Melalui MetodeBernyanyi di MTs MA'ARIF NU 02 Cilongkok Kab. Banyumas. IAIN Purwokerto.

Riyadi, S. (2014). Strategi Pembelajaran Bunyi dan Mufrodat. At-Tajdid: Jurnal Ilmu Tarbiyah, 3(2).

Yusriana, A. (2012). Kiat-kiat Menjadi Guru PAUD yang disukai anak-anak. Diva Press. 